\title{
Developing a Building Information Modelling Educational Framework for the Tertiary Sector in New Zealand
}

\author{
Garry Miller, Shubham Sharma, Claire Donald, and Robert Amor \\ University of Auckland, New Zealand \\ g.miller@auckland.ac.nz
}

\begin{abstract}
Whilst Building Information Modelling (BIM) is rapidly being acknowledged as a driver for change in the Architectural, Engineering and Construction sector across the globe, the introduction of BIM into graduate and postgraduate teaching programmes in the tertiary sector in New Zealand has been minimal to date. New Zealand has an advanced albeit small economy, and whilst BIM is being deployed increasingly with effect in industry, there is no national BIM education framework and only one tertiary sector institution offers any BIM teaching in New Zealand (NZ). This paper reviews the current approaches to incorporating BIM into degree and certificate programmes in 25 leading international universities, pedagogical approaches and BIM critical success factors. A draft of a BIM educational framework for NZ is proposed based on this review. An approach for further design, development and deployment of the framework is also offered. This paper is intended to initiate debate and to start to build consensus between the academic community and industry on a national BIM educational framework for New Zealand.
\end{abstract}

Keywords: Building Information Modelling, Tertiary Education, Framework.

\section{Introduction}

Building Information Modelling (BIM) is "a digital representation of physical and functional characteristics of a facility. A building information model is a shared knowledge resource of information about a facility forming a reliable basis for decisions during its life-cycle; defined as existing from earliest conception to demolition" (National Institute of Building Sciences, 2007). BIM is being advocated by many as a catalyst for change, poised to reduce the industry's fragmentation and increase its efficiency by improving the communication between project teams (Succar, 2009).

BIM has been identified by the New Zealand Productivity Partnership (a partnership established between government and industry) as a new technology which integrates data and knowledge management to minimize inefficiencies and enhance the value delivered during design, build and operation (Kane, 2012). Implementation of BIM in NZ is one of four major work-streams in the Productivity Partnership's programme to deliver a productivity improvement of $20 \%$ by 2020 . 
There are some early adopters of BIM in New Zealand (NZ). There is evidence that some organisations are already deriving benefits from using BIM including improved project design, co-ordination, planning, project delivery and bottom line performance improvements (Huber, 2012). However, from anecdotal evidence it would appear that organisations doing so are the larger companies with international operations, who are able to gain benefits by transferring knowledge from overseas. As such, whilst BIM has the potential to significantly improve performance of organisations, in NZ it is not widely understood nor harnessed by New Zealand industry generally. A concurrent issue is also an almost complete lack of BIM educational provision by the NZ tertiary sector institutions, which exacerbates the slow adoption of BIM. Therefore is a need in New Zealand to develop an educational framework for the tertiary sector in order to enhance knowledge and skills in the local context.

To address this challenge the University of Auckland has developed a collaborative research and educational programme for BIM issues related to the Architectural, Engineering and Construction (AEC) sector in NZ. This programme is a collaboration between several parties, including other tertiary sector organisations and industry. This paper offers a draft educational framework to initiate debate and to start to build consensus in the academic community on a national BIM educational framework for New Zealand.

\section{Literature Review: Background and Contemporary Issues for New Zealand}

Despite the recent global interest in BIM it is in actual fact an old idea, with origins in the 1970's (Eastman et al., 2008). It has taken almost 40 years to become the commercially attractive tool that is so widely praised today (Bernstein, 2005). Perhaps the best evidence of its potential to add value to the construction industry is its widespread uptake by countries such as (but not limited to) the United States, United Kingdom, Denmark, the Netherlands, Finland, and Australia. However, in New Zealand a recent survey found that of 417 respondents, $10 \%$ do not understand what $\mathrm{BIM}$ is, $60 \%$ have some understanding, a further $20 \%$ have a reasonable appreciation of BIM's potential and only a final $10 \%$ have a clear appreciation of the advantages of BIM (Huber, 2012). As such BIM is still at the development stage of the typical product life cycle in the context of NZ.

Tran et al. (2012) make a case for establishing a BIM research framework in NZ, and identify three reasons why BIM has not been widely used namely: slow uptake by companies; a lack of NZ-focused initiatives; and a lack of BIM-based building life cycle considerations. Of these three reasons the first appears to be a circular argument. The second reason is well made, and despite interest in BIM from policy makers, it would appear that there is no real appetite by political leaders to drive BIM implementation at a policy level. The third reason would appear to have some validity, but is not unique to New Zealand.

Other specific issues relating to the NZ context are the structure of NZ industry, the Canterbury post earthquake re-build, NZ regulatory issues relating to consenting 
processes, and the educational provisions in BIM. We discuss the structural issues and the educational provisions in more detail in the following sections.

Issues relating to BIM adoption by small to medium sized enterprises (SMEs) are particularly relevant for New Zealand. SMEs are defined in NZ as businesses that employ fewer than 20 full-time staff. More than $96 \%$ of businesses in the AEC sector are in this category (MED, 2011). Access to new technology, performance improvement approaches and training is often limited for SMEs by the lack of awareness of innovative processes, technologies and practices. This is primarily due to the costs of acquisition of new technologies and of training (Eastman and Sacks, 2008).

Furthermore, evidence is evolving from overseas that adoption of BIM models and processes by SMEs can represent a strategic driver for the performance improvement within the SME section of the AEC industry (Gledson et al., 2012, Sebastian et al., 2009). When there are early adopters within the SME community, their example helps leverage on-going introduction of BIM across industry.

Jayasena et al. (2012) and Wong et al. (2011) emphasise that for BIM expansion, we need more BIM trained professionals in the AEC industry, and that such people are very hard to find because of insufficient BIM training and education. The essential training in this regard is needed for students in tertiary educational institutes.

Gier (2007) carried out a research study in the USA to examine if BIM should be taught as a subject to construction management students. He conducted two questionnaire surveys targeted at general contractors and construction management programs. Based on the collected data, he concluded that construction management programs should teach BIM to their students.

In another study, Woo (2007) pointed out that properly structured BIM courses would provide industry-required knowledge to prepare students for successful careers in the AEC industry. Instead of teaching a separate course, he suggested restructuring existing construction courses to integrate BIM into the course content.

Whilst these studies are informative, their paradigm is from the perspective of BIM rather than from the perspective of educational design. We therefore provide a brief overview of some of the literature on educational frameworks, together with a proposed development approach in a later section of this paper.

\section{Developing the Draft Educational Framework}

In developing a draft educational framework for BIM we have considered a number of factors, namely:

1. Contextual issues for New Zealand;

2. Critical success factors for BIM implementation from international literature;

3. Review of existing BIM educational programmes offered by leading international universities;

4. Pedagogical approaches to the design of educational frameworks.

We have already provided an overview of context issues for New Zealand in the literature review, and the following sections of this paper consider the remaining factors before offering a draft framework. 


\section{BIM Critical Success Factors}

Table 1 is a comparison of BIM success factors including enterprise resource planning, new product development and project management success factors from different authors, categorized into people, process, management and technology factors.

Table 1. BIM Critical Success Factors

\begin{tabular}{|c|c|c|c|c|c|c|}
\hline $\begin{array}{l}\text { BIM } \\
\text { success } \\
\text { factors } \\
\end{array}$ & $\begin{array}{l}\text { Pinto et al. } \\
(1987)\end{array}$ & Lester (1998) & $\begin{array}{l}\text { Zhang (2003, } \\
\text { 2009) }\end{array}$ & $\begin{array}{l}\text { Autodesk } \\
\text { (2007) }\end{array}$ & $\begin{array}{l}\text { Staub-French } \\
\text { et al. (2007) }\end{array}$ & Mom (2011) \\
\hline $\begin{array}{l}\text { Process } \\
\text { Factors }\end{array}$ & $\begin{array}{l}\text { Clearly } \\
\text { defined goals }\end{array}$ & $\begin{array}{l}\text { Senior } \\
\text { management } \\
\text { commitment }\end{array}$ & $\begin{array}{l}\text { Comprehensi } \\
\text { ve survey and } \\
\text { assessment }\end{array}$ & $\begin{array}{l}\text { Sound } \\
\text { implementatio } \\
\text { n strategy }\end{array}$ & $\begin{array}{l}\text { Identifying } \\
\text { uses of 3D } \\
\text { models and } \\
\text { model } \\
\text { requirements }\end{array}$ & $\begin{array}{l}\text { BIM models } \\
\text { for submittal } \\
\text { and approval, } \\
\text { step-by-step } \\
\text { testing }\end{array}$ \\
\hline $\begin{array}{l}\text { Manage- } \\
\text { ment } \\
\text { factors }\end{array}$ & $\begin{array}{l}\text { Competent } \\
\text { project } \\
\text { management }\end{array}$ & $\begin{array}{l}\text { Organizationa } \\
1 \text { structure and } \\
\text { processes to } \\
\text { support } \\
\text { venture }\end{array}$ & $\begin{array}{l}\text { Efficient } \\
\text { project } \\
\text { management } \\
\text { team }\end{array}$ & $\begin{array}{l}\text { Assembling } \\
\text { the right team }\end{array}$ & $\begin{array}{l}\text { Developing } \\
\text { protocol for } \\
\text { addressing } \\
\text { design } \\
\text { questions }\end{array}$ & $\begin{array}{l}\text { BIM } \\
\text { standards, } \\
\text { codes, rules } \\
\text { and } \\
\text { regulations }\end{array}$ \\
\hline $\begin{array}{l}\text { People } \\
\text { factors }\end{array}$ & $\begin{array}{l}\text { Top } \\
\text { management } \\
\text { support }\end{array}$ & $\begin{array}{l}\text { Attract new } \\
\text { product } \\
\text { concepts } \\
\text { available for } \\
\text { development }\end{array}$ & $\begin{array}{l}\text { Improve } \\
\text { project } \\
\text { management } \\
\text { information } \\
\text { system }\end{array}$ & $\begin{array}{l}\text { Training for } \\
\text { BIM }\end{array}$ & $\begin{array}{l}\text { Establishing } \\
\text { conflict } \\
\text { resolution } \\
\text { process }\end{array}$ & $\begin{array}{l}\text { Pre- } \\
\text { qualification } \\
\text { of team, } \\
\text { matching } \\
\text { project goals } \\
\text { with team } \\
\text { goals }\end{array}$ \\
\hline $\begin{array}{l}\text { Techn- } \\
\text { ology } \\
\text { factors }\end{array}$ & $\begin{array}{l}\text { Standard } \\
\text { equipment, } \\
\text { Sufficient } \\
\text { resource } \\
\text { allocation }\end{array}$ & $\begin{array}{l}\text { Venture } \\
\text { teams with } \\
\text { appropriate } \\
\text { staffing and } \\
\text { resources }\end{array}$ & $\begin{array}{l}\text { Need to } \\
\text { embrace } \\
\text { change and } \\
\text { continuous } \\
\text { improvement }\end{array}$ & & $\begin{array}{l}\text { Establishing } \\
\text { drawing } \\
\text { protocol }\end{array}$ & $\begin{array}{l}\text { Technical } \\
\text { support } \\
\text { including } \\
\text { training }\end{array}$ \\
\hline
\end{tabular}

By analyzing the table, it can be clearly seen that for process factors, most of the authors focus on a sound and clear objective or strategy by identifying the goals. On management factors, most of the authors recommend implementing in an integrated team-based approach while maintaining well-defined rules. For people factors, training and employee support as well as having the right expertise are identified as essential. Lastly, for technology factors, technical support, efficient hardware and software, sufficient resource allocation and standard equipment are considered critical factors. We believe these success factors are informative for design of a BIM educational approach.

\subsection{Review of BIM Educational Programmes}

We reviewed the current BIM educational programmes in the 25 leading international universities for engineering according to the Times Higher University Rankings (2012). We did keyword searches on the main website of the top 25 universities, and also specifically searched for "BIM Course Outline". The name of the BIM course, the subject level, duration of the course and teaching method were identified at both 
undergraduate and postgraduate levels. Also, the same approach was used to search for BIM courses for the eight universities in New Zealand in order to compare trends.

Out of all the top 25 universities in the world for engineering, 16 of them are currently teaching BIM courses as summarized in Figure 1.

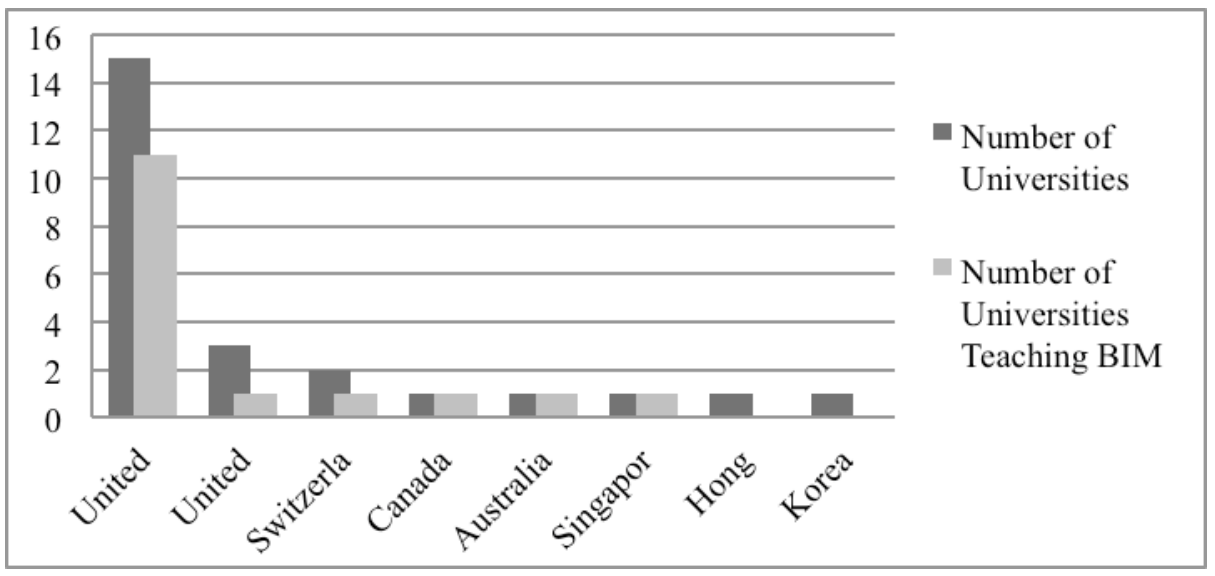

Fig. 1. BIM Education Provision in Leading Universities for Engineering

The duration of most of the courses in the universities is one semester, with 15 out of 16 having semester-long BIM courses. Also, the preferred level of teaching BIM courses is at undergraduate level, with 9 out of 16 universities teaching BIM courses at this level. Six out of 16 universities also have some BIM courses at Masters level, while only 3 universities have certificate level courses. A list of the universities and further details of their BIM course offerings are provided in the Appendix.

Of the 8 universities in New Zealand none currently have a taught course or progamme at Bachelor or Masters level in BIM. However, there is a good track record in BIM research in New Zealand, which positions universities in New Zealand well for developing research informed BIM educational programmes. Only Unitec Institute of Technology (a polytechnic) has BIM courses, which appear to be orientated towards skills development and vocational training. Therefore, there is currently a gap in the educational sector in New Zealand for providing university level education at Bachelor and taught Masters levels.

\section{A Pedagogical Approach to the Design of a BIM Educational Framework for NZ}

We propose that a starting point for designing a new educational framework for BIM in New Zealand is to conduct a comprehensive needs analysis according to the widely used ADDIE model (Analysis, Design, Development, Implementation, Evaluation) of instructional design (Dick et al., 2005). This establishes the extent and nature of the demand in the various sectors of the BIM professional community, the requirements of key stakeholders, necessary educational, technical and funding resources as well as 
the characteristics of the potential students. The research reported in this paper provides the basis for such a needs analysis.

The results of the completed needs analysis will inform the design of the educational framework for BIM. During this second stage we will determine the goals and intended learning outcomes for the curriculum, its structure, and plan the teaching and assessment methods. An initial set of goals and outcomes are proposed later in this paper. The central question we address during this process is: what is most important for the students to know, to be able to do, and what are the best ways for them to learn this? (Toohey, 1999).

Approaches to curriculum design at university tend to fall into five categories (Toohey, 1999): traditional, or discipline-based; performance- or systems-based; cognitive; personal relevance or experiential; and socially critical. These are not necessarily applied discretely. Indeed, we propose to combine elements from three of these categories to designing a national BIM framework: the traditional or disciplinebased approach, (the BIM educational framework will be divided into topics based on the important concepts); the performance or systems-based approach, (support particular teaching and learning methods according to clear and assessable objectives) and the cognitive approach (students will be helped to develop specific intellectual abilities and conceptual structures required for problem solving across multidisciplinary domains).

Crucial to devising a successful national BIM programme for tertiary students will be applying Biggs' strategy of constructive alignment (Biggs, 1996). This involves aligning the intended learning outcomes, assessment methods and planned learning opportunities closely with one another. In addition, we will ensure that flexible elearning opportunities are incorporated appropriately, using an integrated e-learning framework which has been successfully applied in other degree programmes (Blake and Doherty, 2008).

Currently underpinning our approach to this design are the theories of authentic learning and situated cognition (Brown et al., 1989). These place primary importance on the real-life context of learning, suggesting that for learning to be effective and meaningful, it must occur in the same context in which it will be used and applied in the future, similar to apprenticeship training. In a tertiary education context, authentic learning environments include a number of key elements proposed by Herrington, Reeves and Oliver (2010), which we would aim to incorporate in a new curriculum for BIM. These include providing authentic learning activities, access to expert performances and modeling of processes, adopting multiple roles and perspectives, collaborative construction of knowledge, and authentic assessment of learning within the tasks.

We believe that this approach will provide the sound pedagogical basis required as we move forward with the planning and development of a new BIM framework for the tertiary education sector in NZ.

\section{Proposed Draft Framework}

In developing a proposed educational framework for BIM in the tertiary sector for New Zealand we identified disciplines (knowledge domains) and mapped them 
against the NZQF. One of the challenges of devising a BIM education programme is that BIM crosses a number of traditional disciplinary boundaries. BIM certainly crosses the architectural, engineering and construction domains, and the AEC industry is often defined as a sector. However BIM is also an approach that integrates technology and software development together with business, enterprise and management. We illustrate the relationship between these sectors in a Venn Diagram in Figure 2. In devising such an integrated approach across disciplines we seek to incorporate some of the BIM critical success factors identified earlier in this paper.

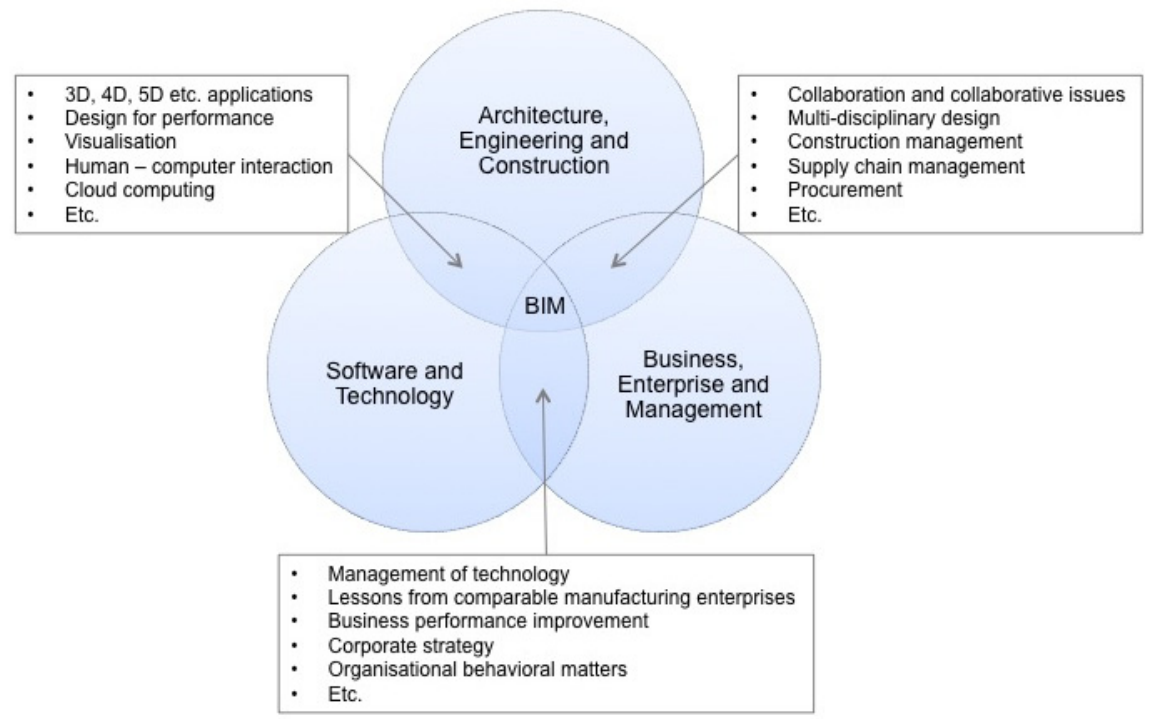

Fig. 2. Venn Diagram Showing Discipline Relationships for BIM

We also believe that an educational framework should encompass three broad types of education: vocational training / continuing professional development, degree programmes (taught), and research (including $\mathrm{PhD}$ programmes). The requirements in each of these are different, and so the framework needs to be designed to serve the diverse educational needs of a broad spectrum of stakeholders. Our draft framework is presented in Figure 3.

In the architectural design representation, BIM enforces a migration from two to three dimensions by creating intelligent, multi-dimensional building models. Hence, in reality BIM goes beyond simply representing the geometry of a building. As such BIM is not just a new way of drafting and is not a technique that might be taught like technical drawing. Rather it is a more fundamental approach which needs to be studied and well understood. BIM views can show and intelligently interpret the types of materials and construction details including scheduling of building elements for assembly. Through this capability BIM provides an opportunity for various users with different backgrounds to work collaboratively across traditional disciplines. 
One of the debates in BIM education is the question of whether BIM should be integrated into existing curricula of architecture and engineering degrees (i.e. by integrating BIM into teaching on existing papers), or whether it should be taught as a specific topic in its own right. We take a pragmatic view that it probably needs to be a combination of both, with an incremental, organic integration into existing Bachelor level degrees probably being the more acceptable and sustainable approach. However incremental change in tertiary sector can be slow, and there is an argument to be made for an integrated degree targeted at mature students who have gained some industry experience and are seeking to gain specialized knowledge and skills in BIM. Hence we also propose an integrated postgraduate course delivered as a taught masters degree. Such a degree should cross the boundaries of traditional disciplines, and ideally should be a collaboration between faculties and even between different universities. Whilst such collaborations can be difficult to achieve in practice they are not impossible, and given that BIM typically facilitates collaboration in industry, we argue that it should do so in academia also. Development of a specialist taught Masters programme provides a possible avenue for collaboration.

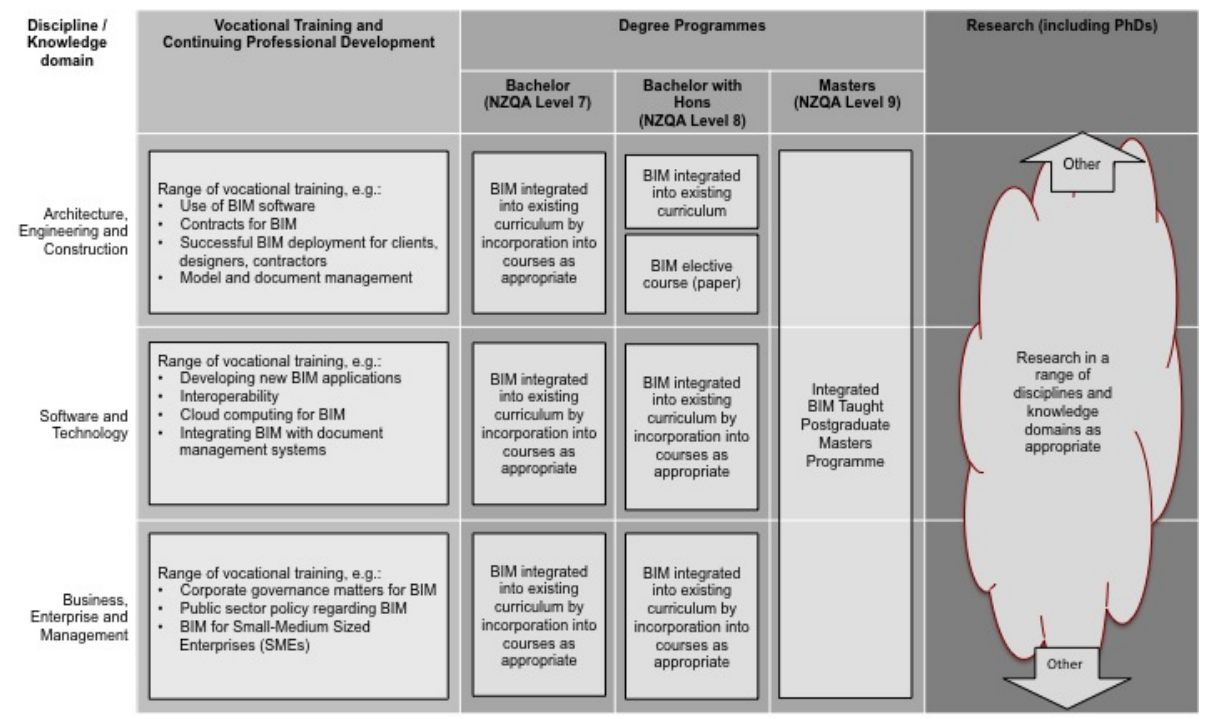

Fig. 3. Draft BIM Educational Framework for New Zealand

While it is premature to define the content of the educational programmes, goals should be identified. We have attempted to draft a set of goals and intended learning outcomes to stimulate debate. These are presented in Table 2: 
Table 2. Suggested Goals for New Zealand BIM Education Framework

\begin{tabular}{|c|c|}
\hline $\begin{array}{l}\text { Element of } \\
\text { Framework }\end{array}$ & Goals \\
\hline $\begin{array}{l}\text { National BIM } \\
\text { Educational } \\
\text { Framework }\end{array}$ & $\begin{array}{l}\text { 1. The framework is accepted by all tertiary sector organisations in } \\
\text { NZ; } \\
\text { 2. Universities and other tertiary sector education providers } \\
\text { collaborate on teaching and research; } \\
\text { 3. The New Zealand BIM educational framework is acknowledged as } \\
\text { being world class in international comparators; } \\
\text { 4. The BIM educational programme leads NZ industry towards the } \\
\text { mature phase of the BIM technology lifecycle. }\end{array}$ \\
\hline BIM research & $\begin{array}{l}\text { 1. A dynamic programme of research, extending knowledge at the } \\
\text { most advanced level; } \\
\text { 2. Research supported and funded by industry and public sector } \\
\text { working in partnership with the tertiary sector; } \\
\text { 3. Some commercialization of the best research outputs }\end{array}$ \\
\hline BIM taught & Students completing the degree: \\
\hline Masters degree & $\begin{array}{l}\text { 1. Have advanced understanding of underpinning key principles of } \\
\text { BIM, with an ability to discern what BIM can and cannot do; } \\
\text { 2. Are able to create and manage 3D models, and some of the } \\
\text { extension applications into 4D, 5D etc.; } \\
\text { 3. Have the knowledge and skills in a range of topics including (but } \\
\text { not limited to): collaboration, BIM procurement issues, } \\
\text { management of technology, business performance improvement, } \\
\text { software development, database systems etc.; } \\
\text { 4. Are able to undertake research on at least one specialized topic } \\
\text { relating to BIM; } \\
\text { 5. Are able to use a variety of BIM software; } \\
\text { 6. Are able to introduce BIM into their employer organisations; } \\
\text { 7. Are able to use BIM effectively in a range of design and /or } \\
\text { construction scenarios. }\end{array}$ \\
\hline $\begin{array}{l}\text { Existing bachelor } \\
\text { degree } \\
\text { programmes in } \\
\text { AEC sector }\end{array}$ & $\begin{array}{l}\text { BIM is integrated into the existing curricula in Architecture and } \\
\text { Engineering degree programmes: } \\
\text { 1. Graduates have a sound understanding of underpinning key } \\
\text { principles of BIM; } \\
\text { 2. Understanding of 3D modeling techniques and ability to } \\
\text { manipulate 3D models; } \\
\text { 3. Appreciation of the wide range of benefits derived from BIM } \\
\text { 4. Able to use a variety of BIM software; } \\
\text { 5. Able to use BIM effectively in a range of design and /or } \\
\text { construction scenarios. }\end{array}$ \\
\hline $\begin{array}{l}\text { Vocational } \\
\text { training and CPD } \\
\text { education }\end{array}$ & $\begin{array}{l}\text { 1. An active and dynamic programme of vocational training and CPD } \\
\text { to meet the training needs of industry; } \\
\text { 2. Accessible and affordable training for a diverse New Zealand } \\
\text { sector with significant portion of SMEs; } \\
\text { 3. Awareness and knowledge at all levels of industry of benefits of } \\
\text { BIM. }\end{array}$ \\
\hline
\end{tabular}


In order to measure the success of achieving the BIM educational goals we plan to implement a longitudinal study to gather data on learning outcomes and uptake of graduates being offered employment in industry in BIM related roles. In order to broaden the relevance of this research to the international community we are seeking collaborations to benchmark outcomes with the tertiary sector in other parts of the world.

\section{Future Work}

We outlined our planned pedagogical approach to the design of an educational framework in a previous section. To facilitate the development of the framework we will seek to establish collaboration with the other tertiary institutes in New Zealand, industry and other interested stakeholders such as professional bodies, trade associations, the Productivity Partnership, Building Research Association of New Zealand and the Ministry of Business, Innovation and Employment. There is a range of practical mechanisms we will seek to introduce including formation of an advisory group, and establishment of a funded BIM research and educational programme. An injection of funding from the public sector is needed to kick-start such a programme, as industry-led funding is unlikely to be forthcoming due to the early stage in the technology life-cycle and fragmented nature of industry in the AEC sector. An important future stage will be to derive the intended learning outcomes and align them with appropriate assessment strategies. Further research is needed to develop (or redraft as appropriate) the learning outcomes proposed in this paper. Such research must seek to identify the particular needs of SME's. The formulation of intended learning outcomes in partnership with industry will help to ensure the educational framework meets the needs of NZ industry.

\section{Conclusions}

We have argued that New Zealand AEC sector is at the early development stage of BIM life-cycle, and that whilst the potential of BIM is generally recognised there are barriers to wider implementation of BIM, particularly the structure of NZ industry and the lack of BIM educational provision. Whilst the international tertiary sector has already established BIM educational courses and programmes, there is an almost complete lack of BIM educational provision at undergraduate and taught postgraduate levels in New Zealand: a deficiency that must be tackled. As a first stage in addressing this issue we have offered a draft educational framework for NZ, which seeks to incorporate disciplines across traditional boundaries, that is based on well-founded pedagogical principles, acknowledges BIM critical success factors, is informed by overseas programmes, and focused on learning outcomes. This framework is offered to initiate debate and to start to build consensus between the academic community and industry on a national BIM educational framework for New Zealand. 


\section{References}

Autodesk, Transitioning to BIM (2007), http: / /static.ziftsolutions.com/ files/8a7c9fef2693aale0126d28c29d806ac

Bernstein, P.: Integrated Practice: It's not just about the technology. The American Institute of Architects (2005), http: / / info.aia.org/aiarchitect/thisweek05/ tw0930/tw0930bp_notjusttech. cfm (accessed October 31, 2012)

Biggs, J.: Enhancing teaching through constructive alignment. Higher Education 32, 347-364 (1996)

Blake, A., Doherty, I.: An Instructional Design Course for Clinical Educators: First Iteration Design Research Reflections. Journal of Learning Design 2(2), 104-115 (2008)

Brown, J., Collins, A., Duguid, P.: Situated cognition and the culture of learning. Educational Researcher 18(1), 32-42 (1989)

Dick, W., Carey, L., Carey, J.: The systematic design of instruction. Pearson (2005)

Eastman, C.M., Sacks, R.: Relative Productivity in the AEC Industries in the United States for On-Site and Off-Site Activities. Journal of Construction Engineering and Management 134, 517-526 (2008)

Eastman, C.M., Teicholz, P., Sacks, R., Liston, K.: BIM handbook: A guide to building information modeling for owners, managers, architects, engineers, contractors and fabricators. John Wiley and Sons, Hoboken (2008)

Gier, D.: Does learning building information modeling improve the plan reading skills of construction management students? (2007), http: / / ascpro0 .ascweb.org/archives /2007/CEUE146002007.pdf

Gledson, B., Henry, D., Bleanch, P.: Does Size Matter? Experiences and Perspectives of BIM Implementation From Large and Sme Construction Contractors. In: 1st UK Academic Conference on Building Information Management (BIM), Northumbria University, Newcastle upon Tyne, UK (2012)

Herrington, J., Reeves, T., Oliver, R.: A guide to authentic learning. Routledge, New York (2010)

Huber, R.: New Zealand National BIM Survey 2012. Masterspec - Construction Information Ltd. (2012)

Jayasena, H.S., Weddikkara, C.: Building Information Modelling for Sri Lankan Construction Industry (2012), http: / / www . academia . edu/1772647 / Building_ Information_Modelling_for_Sri_Lankan_Construction_Industry

Kane, C.: Productivity Roadmap. Building and Construction Sector Productivity Partnership (2012)

Lester, D.H.: Critical success factors for new product development. Research Technology Management 41, 36-43 (1998)

Mom, M.: On Decision-making and Technology Implementing Factors for BIM Adoption (2011), http: / / www . academia. edu/894660/On_Decisionmaking_and_Technology-implementing_Factors_for_BIM_Adoption

National Institute of Building Sciences 2007, NIST, National building information modeling standard. Version 1 - Part 1: Overview, principles and methodologies (2007)

Pinto, J.K., Slevin, D.P.: Critical Factors in Successful Project Implementation. IEEE Transactions on Engineering Management EM-34, 22-27 (1987) 
Sebastian, R., Haak, W., Vos, E.: BIM application for integrated design and engineering in small-scale housing development: a pilot project in The Netherlands. In: Proceedings of International Symposium CIB-W096 Future Trends in Architectural Management, Tainan, Taiwan, November 2-3 (2009)

Staub-French, S., Khanzode, A.: 3D and 4D modeling for design and construction coordination: issues and lessons learned. ITcon 12, 381-407 (2007)

Succar, B.: Building information modelling framework: A research and delivery foundation for industry stakeholders. Automation in Construction 18, 357-375 (2009)

Times Higher Education, World University Rankings (2012), http://www.timeshighereducation.co.uk/world-universityrankings/2012-13/subject-ranking/subject/engineering-and-IT (accessed December 9, 2012)

Toohey, S.: Designing Courses for Higher Education. Open University Press, Philadelphia (1999)

Tran, V., Tookey, J.E., Roberti, J.: Shaving BIM: Establishing a Framework for Future BIM Research in New Zealand. International Journal of Construction Supply Chain Management 2, 66-79 (2012)

Wong, K.A., Wong, K.F., Nadeem, A.: Building information modelling for tertiary construction education in Hong Kong. ITcon (2011)

Woo, J.H.: BIM (Building Information Modeling) and Pedagogical Challenges. In: Proceedings of the 43rd Annual Conference by Associated Schools of Construction (2007)

Zhang, L., Lee, M.K.O., Zhang, Z., Banerjee, P.: Critical success factors of enterprise resource planning systems implementation success in China. In: Proceedings of the 36th Annual Hawaii International Conference on System Sciences, 10 p. IEEE (2003)

Zhang, Y., Guangbin, W.: Cooperation between Building Information Modeling and Integrated Project Delivery Method Leads to Paradigm Shift of AEC Industry. In: Management and Service Science, September 20-22, pp. 1-4 (2009) 


\section{Appendix}

\begin{tabular}{|c|c|c|c|c|c|c|c|}
\hline \# & Institution & Country & $\begin{array}{l}\text { BIM } \\
\text { course }\end{array}$ & $\begin{array}{l}\text { Teaching } \\
\text { method }\end{array}$ & Duration & Course Name & Level \\
\hline 1 & $\begin{array}{l}\text { California Institute of } \\
\text { Technology }\end{array}$ & $\begin{array}{l}\text { United } \\
\text { States }\end{array}$ & No & - & - & - & - \\
\hline 2 & Princeton University & $\begin{array}{l}\text { United } \\
\text { States }\end{array}$ & No & - & - & - & - \\
\hline 3 & $\begin{array}{l}\text { Massachusetts Institute of } \\
\text { Technology }\end{array}$ & $\begin{array}{l}\text { United } \\
\text { States }\end{array}$ & Yes & $\begin{array}{l}\text { Thesis, } \\
\text { Coursework }\end{array}$ & $\begin{array}{l}\text { One } \\
\text { Semester }\end{array}$ & $\begin{array}{l}\text { Computational Design } \\
\text { Lab: Reinventing BIM }\end{array}$ & $\begin{array}{l}\text { Bachelors } \\
\text { Masters }\end{array}$ \\
\hline 4 & $\begin{array}{l}\text { University of California, } \\
\text { Berkeley, Berkeley }\end{array}$ & $\begin{array}{l}\text { United } \\
\text { States }\end{array}$ & Yes & Coursework & $\begin{array}{l}\text { One } \\
\text { Semester }\end{array}$ & $\begin{array}{l}\text { Fundamentals of } \\
\text { Building Information } \\
\text { Modeling, Revit, } \\
\text { Advanced Revit }\end{array}$ & Certification \\
\hline 5 & Stanford University, University & $\begin{array}{l}\text { United } \\
\text { States }\end{array}$ & Yes & Coursework & $\begin{array}{l}\text { One } \\
\text { Semester }\end{array}$ & $\begin{array}{l}\text { Building Information } \\
\text { Modeling }\end{array}$ & Bachelors \\
\hline 5 & University of Cambridge & UK & Yes & Research & $>$ One Year & $\begin{array}{l}\text { Infrastructure As-Built } \\
\text { Modeling }\end{array}$ & \\
\hline 7 & $\begin{array}{l}\text { University of California, Los } \\
\text { Angeles }\end{array}$ & $\begin{array}{l}\text { United } \\
\text { States }\end{array}$ & Yes & $\begin{array}{l}\text { Online } \\
\text { Coursework }\end{array}$ & $\begin{array}{l}\text { One } \\
\text { Semester }\end{array}$ & $\begin{array}{l}\text { Introduction to Building } \\
\text { Information Modeling }\end{array}$ & Certification \\
\hline 8 & $\begin{array}{l}\text { ETH Zürich - Swiss Federal } \\
\text { Institute of Technology Zürich }\end{array}$ & Switzerland & Yes & Coursework & $\begin{array}{l}\text { One } \\
\text { Semester }\end{array}$ & LowEx + Arch & Masters \\
\hline 9 & $\begin{array}{l}\text { Georgia Institute of } \\
\text { Technology }\end{array}$ & $\begin{array}{l}\text { United } \\
\text { States }\end{array}$ & Yes & $\begin{array}{l}\text { Coursework, } \\
\text { Thesis }\end{array}$ & $\begin{array}{l}\text { One } \\
\text { Semester }\end{array}$ & $\begin{array}{l}\text { BIM: Case studies, BIM } \\
\text { for building construction }\end{array}$ & $\begin{array}{l}\text { Bachelors, } \\
\text { Masters }\end{array}$ \\
\hline 10 & Imperial College London & UK & No & - & - & - & - \\
\hline 11 & University of Oxford & UK & No & - & - & - & - \\
\hline 12 & $\begin{array}{l}\text { National University of } \\
\text { Singapore }\end{array}$ & Singapore & Yes & $\begin{array}{l}\text { Coursework, } \\
\text { Workshop }\end{array}$ & $\begin{array}{l}\text { One } \\
\text { Semester }\end{array}$ & $\begin{array}{l}\text { Integrated design and } \\
\text { sustainability }\end{array}$ & Bachelors \\
\hline 13 & University of Texas at Austin & $\begin{array}{l}\text { United } \\
\text { States }\end{array}$ & Yes & Coursework & $\begin{array}{l}\text { One } \\
\text { Semester }\end{array}$ & BIM for capital projects & Bachelors \\
\hline 14 & $\begin{array}{l}\text { École Polytechnique Fédérale } \\
\text { de Lausanne }\end{array}$ & Switzerland & No & - & - & - & - \\
\hline 15 & Carnegie Mellon University & $\begin{array}{l}\text { United } \\
\text { States }\end{array}$ & Yes & $\begin{array}{l}\text { Coursework, } \\
\text { Workshop }\end{array}$ & $\begin{array}{l}\text { One } \\
\text { Semester, } \\
\text { Three days }\end{array}$ & $\begin{array}{l}\text { Advanced CAD, BIM, } \\
\text { and 3D Visualization }\end{array}$ & $\begin{array}{l}\text { Masters, } \\
\text { Research }\end{array}$ \\
\hline 16 & North Western University & $\begin{array}{l}\text { United } \\
\text { States }\end{array}$ & Yes & Coursework & $\begin{array}{l}\text { One } \\
\text { Semester }\end{array}$ & $\begin{array}{l}\text { Various } 100,200 \text { and } \\
400 \text { level BIM courses }\end{array}$ & $\begin{array}{l}\text { Bachelors, } \\
\text { Masters }\end{array}$ \\
\hline 17 & $\begin{array}{l}\text { University of California, Santa } \\
\text { Barbara }\end{array}$ & $\begin{array}{l}\text { United } \\
\text { States }\end{array}$ & No & - & - & - & - \\
\hline 18 & Cornell University & $\begin{array}{l}\text { United } \\
\text { States }\end{array}$ & Yes & Coursework & $\begin{array}{l}\text { One } \\
\text { Semester }\end{array}$ & $\begin{array}{l}\text { Introduction to Revit and } \\
\text { BIM }\end{array}$ & Bachelors \\
\hline 19 & University of Michigan & $\begin{array}{l}\text { United } \\
\text { States }\end{array}$ & No & - & - & - & - \\
\hline 20 & $\begin{array}{l}\text { University of Illinois at Urbana } \\
\text { Champaign }\end{array}$ & $\begin{array}{l}\text { United } \\
\text { States }\end{array}$ & Yes & Workshop & One day & $\begin{array}{l}\text { Autodesk Revit Training } \\
\text { Workshop: BIM }\end{array}$ & Certification \\
\hline 21 & Columbia University & $\begin{array}{l}\text { United } \\
\text { States }\end{array}$ & Yes & Coursework & $\begin{array}{l}\text { One } \\
\text { Semester }\end{array}$ & Re-Thinking BIM & Bachelors \\
\hline 22 & University of Toronto & Canada & Yes & Coursework & $\begin{array}{l}\text { One } \\
\text { Semester }\end{array}$ & $\begin{array}{l}\text { Building Information } \\
\text { Modeling }\end{array}$ & Bachelors \\
\hline 23 & $\begin{array}{l}\text { Hong Kong University of } \\
\text { Science and Technology }\end{array}$ & Hong Kong & No & - & - & - & - \\
\hline 24 & $\begin{array}{l}\text { Pohang University of Science } \\
\text { and Technology }\end{array}$ & $\begin{array}{l}\text { Republic of } \\
\text { Korea }\end{array}$ & No & - & - & - & - \\
\hline 25 & University of Melbourne & Australia & Yes & Coursework & $\begin{array}{l}\text { One } \\
\text { Semester }\end{array}$ & $\begin{array}{l}\text { Construction } \\
\text { Measurement and } \\
\text { Estimating }\end{array}$ & Masters \\
\hline
\end{tabular}

